\title{
Need Assessment of Learning Inclusive Program for Students in Non-formal Early Childhood Education
}

Ari Putra 1

1LPDP, Universitas Pendidikan Indonesia, Bandung, Indonesia

\begin{abstract}
The concept of inclusive program is organized according to the ability and needs of students for learners to be successful and can optimize the potential within themselves. Currently, inclusive program is newly embodied in formal education programs such as elementary, junior, and senior high schools. The current problem is the clarity of inclusive education program concept implemented in non-formal education, especially in informal early childhood education. This study aims to find out how the assessment process conducted by the teachers of Bunayya Islamic preschool in order to discover the source of learning needs such as students with special needs. The research method used is qualitative method by using triangulation of subject, time, and place. The result of this research shows that Bunayya Islamic preschool makes an initiative to create their own learning concepts without technical guidance such as inclusive curriculum development and lesson plans. Bunayya Islamic preschool runs the learning program by planning, implementing and evaluating the needs of learning resources of children with special needs. In conclusion, the teacher performs several steps such as identification of children with special needs, pre-qualification priorities and the development of the learning curriculum to adopt the learning interpretation and alternative program for pre-schoolers and parent's concepts.
\end{abstract}

\section{KEY WORDS}

need assessment, informal early childhood education, inclusive program

\section{CORRESPONDING AUTHOR:}

email: arie_poetra67@yahoo.co.id

Manuscript submitted June 28, 2018; accepted Agustus 18,

2018.
Copyright: (C2018 This is an open access article under the terms of the Creative Commons Attribution License, which permits unrestricted use, distribution, and reproduction in any medium, provided the original author and source are credited.

\section{INTRODUCTION}

Education is an attempt to shape the attitudes and behavior of human beings in order to become a complete human. Through education, individuals can develop their creativity and ability. In the process of learning, educators and learners are two matters that cannot be separated. The indicator of learning success is a professional educator. This aspect could be measured through quality, competition skills, and the ability to enable students to excel in learning, as well as being able to affect the students' teaching and learning process (Hamalik, 2006, p. 36). There are some things that should be examined in the creating process of learning, which in turn can improve the quality of human resources; they are curriculum, instructional media, teachers and professional educational personnel. Professional educators are expected to be better and be able to create an effective and fun learning 
environment, and have better classroom management. Therefore, these aspects will optimally boost the learners' learning activity. Success in education is not just measured through class attendance at school. The toughest challenge is to ensure that learners acquire quality education, in which they will be able to achieve various learning objectives, finish school, and have capabilities to face future. In order to achieve a quality education, teachers have important and strategic roles.

In the overall dynamics of human development, childhood is the most important period in preparation of qualified human resources. The period of child development takes place rapidly, most sensitive, and a determining aspect in optimizing the next stage of development. Early childhood education has a major role to achieve sustainable development (Siraj, 2009, p. 9). At this time, the child needs various stimuli from environment. When children receive good stimulus, all aspects of child development will develop optimally. Sunardi and Sunaryo $(2007$, p.1) suggested that not every child experience normal development since children have their own development process such as in terms of physical, cognitive, social, emotional, communication, adaptive behavior, retardation, or have their own risk factors, in which they will require special handling or interventions to achieve optimal development. Early intervention is usually developed in inclusive education programs. Inclusive education program is a system of educational services that include children with special needs. Children study together with their peers in a regular school that is located nearest to the place of residence. Education is the foundation of building individuals for a harmonious world (Chan, 2009, p. 9). Inclusive education is an educational concept based upon justice and service to obtain equal opportunity for students in terms of physical, intellectual, emotional or learning aspects (Loreman et al., 2005). Inclusive education also means education for all children including the ones with special need, by merging them with normal child and various learning activities. The existence of this education program is also expected to engender a sense of affection between normal children and children with special needs. Therefore, there is no longer difference between them. Inclusive education program was already adopted and developed by the government. However, it is usually implemented in formal education, and is overlooked in non-formal education program. This research will focus on the non-formal early childhood education program.

Early childhood education is included in the studies of informal education. Regulation of Indonesian Ministry of Education No. 58 of 2009 stated that "Early childhood education is awarding a bid to stimulate, guide, parenting skills and learning activities are granting will produce children's abilities and skills" (2009, para. xx). The programs of early childhood education is included in Law of Republic Indonesia No. 20 of 2003, article 28, which explained that "Early childhood education can be implemented through formal, non-formal, and informal education" (2003, para. 2). Furthermore, in Chapter 4 of Law No. 20 Year 2003, it is emphasized again that early 
childhood education on the formal could be in the forms of Play Group, Daycare and other Early Childhood Education Programs (SPS)" (2003, para. 28).

On its implementation, Indonesian Government has not yet standardized the inclusive service programs for early childhood education programs, while based on data acquired from the Central Bureau of Statistics in Indonesia (BPS), the number of children with special need in Indonesia reached 1.6 million children. The main problem obstructing the operations of inclusive education program is the stigma of certain society against disabled people (Chireshe, 2011, p. 162). Those data require many inclusive services because the number of segregated school located in certain districts are not enough to be the solution for serving children with special need. For addressing the program shortcomings, the educators of Bunayya Islamic Preschool in Bengkulu formulate various innovation in developing the inclusive education service. Originally, the development of inclusive education programs in Bunayya Islamic Preschool was aimed for regular students, but since one of the teachers' child suffers from Autism syndrome, the school also accepts students with special needs. The school is very creative in creating learning resources for students with special needs. The research conducted by the school is considered visionary and a needed change for the good of society. Researchers are interested in digging up information about how the programs were organized by the educators and managers in conducting the assessment of learning resource needs on inclusive education services program in Bunayya Islamic Preschool.

\section{RESEARCH METHODS}

This study used a qualitative method (Musfiqon, 70: 2012). The technique of data collection is done by using participationobservation, open-ended and in-depth interview. At that time, the researchers also did some documentation to acquire more comprehensive data needed. Then, besides doing those two techniques, the researchers also interviewed some teachers in Bunayya Islamic Preschool as respondents.

\section{RESULTS AND DISCUSSION}

The findings acquired from Bunayya Islamic Preschool show that the teachers conducted learning management for student with special need in this school. Based on the data, the process of learning needs assessment in children with special needs in Bunayya Islamic Preschool Bengkulu was by identifying the form of assessment on learners and learning process by implementing playful activities for fun learning.

\section{Identification and Assessment of Children with Special Needs}

In order to acquire the data of learning needs, the school firstly conducted an identification of students with special needs, in which the process acquired one student with autism syndrome. The datum was obtained from the registration done by teachers with how to identify students with special needs. The identification is called networking, and assessment is included as a 
screening process. In general, the purpose of identification is to gather information or data whether or not a child can be included in those with special needs (Hermanto, 2010, p. 11). The identification aims to find children who show certain symptoms, then the result is made into a conclusion of children who suffer from disorders or certain irregularities, in which the child could be included within the category of special needs. The activities meant for identifying children with special needs were conducted by the educators in order to discover the condition of prospective learners who will enroll at Bunayya Islamic Preschool Colloquial learning activities. The results from documentation conducted by researchers that were cross-referenced with the existing archiving in school found a certain method of identification carried out by the school towards the would-be learners. The results of the identification document were in the form of identification of students who were considered of having special needs. From the interview result, it was known that the Principal directed the Admission Committee to conduct a preliminary identification by direct conversation with the potential learners. The type of questions are considered as easy, ranging from introducing oneself, parents' name, other family members, home address, and name of body parts. The purpose of these activities is to see the students' courage and basic knowledge. From this 'interview' activity, the teacher could observe the focus of child's gaze during the short interview process. At that time, teachers identified one student who had symptoms in special need. Often times, teachers found the traits of students with special needs on students with slow conversational skills or the ones who cannot talk at all, answer greeting, able to talk but not in dialog, have odd habits such as walk on tiptoes, like to spin around, avert eye contact while talking, like to carry certain objects that the parents will need to take it away. After investigating, the teachers would also confirm the allegation with the students' parent. From the identification results, the prospective students, who were included in with special needs category, were involved in accordance with their needs. The result of this simple identification process was proceeded with further assessment to design a study that will be applied based on the learning needs of children with special needs in an inclusive classroom. At the next stage, the school actually did not open a special inclusive educational program. This institution did not implement special orthopedagogical method, but the accompanying teachers employed there highly support the continuation of learning even though they do not have certain expertise in teaching children with special needs. Teachers are encouraged to learn through colleagues and few guide books to teach children with special needs. The researchers had a chance to interview the accompanying teacher who taught the children with special need regarding the curriculum used in implementing the learning programs for autistic children enrolled at school. The teacher answered that the compulsory learning program remains the same with the other kids. However, the school also includes extra supplement learning 
material because children with autistic syndrome have higher emotional attitude; and if not supervised, there is a higher risk of injuring regular kids. Therefore, the teacher for children with special needs as the companion at school learned through some coworkers from home therapy.

In order to maximize the learning activities in Bunayya Islamic Preschool, the teacher directed parents to bring children with autistic syndrome in order to obtain additional activity such as therapy. The progress report of child development during the therapy was given to the school for follow up program. The report includes cognitive, affective and psychomotor development of children with special needs such as autistic syndromes. Teachers with Master degree and special companion were encouraged and trained to create learning model that corresponds to the report results from the therapist.

\section{Need Assessment Learning for Students in need of special}

An interesting learning model is indeed very necessary in the process of teaching and learning activities. This is not only applicable for children with special needs, even regular children need unique learning. The teachers at this school do not have different treatment towards the students. During the research, one learning process includes sticking a piece of origami paper made by the teacher. This activity aims to balance the child's psychomotor and affective competencies. The teacher gives the picture without color paper and few pieces of origami paper. Students with special needs are invited to compose pieces of origami paper that will eventually replenish the empty image on the paper. The Working Group invites students in completing the task. The cooperation between pupils with special needs and regular students look normal. This, of course, fulfills the main purpose of the inclusive education program that does not discriminate regular students and students with special needs.

Based on the observation conducted from the side of the children with special needs at Bunayya Islamic Preschool, visual learning is the most effective method for autistic children. At school, children with autistic syndrome are able to draw with 3D design. Children with Autism syndrome have difficulty in communicating at social conditions, which leads to doing repetitive behavior (American Psychiatric Association, 2013).

During the learning need assessment found by the investigators at the site of the research, the teacher always practiced learning by using pictures to explain in more detail to children with special need. Not only focusing on activities to draw or use visual media, students with special needs are also taught with diverse learning mediums. Learning sports activities are also important for children with special needs, motoric activity could also loosen their body, and the teachers often include simple exercise such as dancing while singing before starting their lesson. Teachers also give children with special needs learning movement for moral reinforcement and prayer verses. The students are invited to memorize short Quranic verses. On cognitive learning skills, teachers stimulate learning process by giving questions on the learning 
material. Teachers are only supplement aspects for students to obtain experience. Children are invited to free himself from teachers' scrutiny. Teachers also enhance students' language skill by inviting them to converse with their peers. Bunayya Islamic preschool explains that the students communicate within similar learning method given by the teachers, the distinguishing factor is treatment given by teacher towards students with special needs.

\section{CONCLUSION}

It can be concluded that the learning assessment model implemented by the school is by conducting screening of all prospective students performed and identifying the students with special needs to plan specific learning activities. The school has no special accompanying teachers for children with special needs, empower teachers who do not have basic teaching for special education. The teachers teach based on the existing cases and make use of reference books so that they can learn independently to implement orthopedagogical method. In addition, the school could work closely with specialized therapy institutions for children with special learning needs to understand their needs at schools or at home. Therefore, the development of educational inclusive program is not highly challenging activity to conduct for education providers.

Finally, the research recommends Bunayya Islamic Preschool to keep having children with special needs enrolled at school, avoid from denying these children their learning needs, and starting from now, to make more inclusive activities in schools.

\section{REFERENCES}

American Psychiatric Association. (2013). Diagnostic and statistical manual of mental disorders: DSM-5 (5th ed.). Washington DC: American Psychiatric Publishing.

Chan, B., Choy, G., \& Lee, A. (2009). Harmony as the basis for education for sustainable development: A case example of Yew Chung International Schools. International Journal of Early Childhood 41(2), 35-48.

Chireshe, R., \& Shumba, A. (2011). Teaching as a profession in Zimbabwe: Are teachers facing a motivation crisis? Journal of Social Sciences, 28(2), 158-164.

Hermanto, S. P. (2010). Kemampuan guru dalam melakukan identifikasi anak berkebutuhan khusus di sekolah dasar penyelenggara pendidikan inklusi. Dinamika Pendidikan, 15(1).

Loreman T, Sharma U, Forlin C, \& Earle C. (2005). Pre-service teachers' attitudes and concerns regarding inclusive education. Paper Presented at ISEC2005, Glasgow: Scotland, August 1 to 4, 2005.

Musfiqon, H. M. (2012). Panduan lengkap metodologi penelitian pendidikan. Jakarta: Prestasi Pustaka Raya.

Undang-undang Nomor 58. (2009). Standar Pendidikan Anak Usia Dini.

Undang-undang Nomor 20. (2003). Sistem Pendidikan Nasional (SISDIKNAS). Jakarta: Sinar Grafika.

Siraj-Blatchford, J. (2009). Education for sustainable development in early childhood. International Journal of Early Childhood, 41(2), 9. 
Sunardi, S. (2007). Intervensi dini anak berkebutuhan khusus. Jakarta: Depdiknas. 